\title{
Pendekatan Diagnosis Avian Influenza Virus dan Newcastle Disease Virus pada Kasus Lapangan Ayam Petelur: Imunopatologis Streptavidin Biotin
}

\section{Diagnosis Approach Avian Influenza Virus and Newcastle Dusease Virus at Layer Field Case: Streptavidin Biotin Immunopatologis}

\author{
Maya Ekaningtias', Hastari Wuryastuty ${ }^{2}$, Wasito \\ ${ }^{1}$ Program Studi Bioteknologi, Sekolah Pasca Sarjana, Universitas Gadjah Mada \\ ${ }^{2}$ Fakultas Kedokteran Hewan, Universitas Gadjah Mada \\ Email: mentias4life@gmail.com
}

\begin{abstract}
Poultry can be infected not only by one type of virus, but also by more than one type of virus. Avian influenza virus (AIV) and Newcastle disease virus (NDV) are two important pathogens in poultry that can cause recurrent outbreaks and often lead to clinical symptoms and pathological lesions similar in poultry with high morbidity and mortality causing significant economic losses to the poultry industry. This study aims to detect and differentiate pathogenic viruses in commercial laying chickens with similar clinical symptoms, especially torticolis and curled toe paralysis, and anatomic pathological lesions, such as foci necrotic hemorrhages in the digestive tract by applying streptavidin-biotin immunohistochemical immunological test (IHC SB).

Samples (chickens) were taken from the cases of the disease in poultry in several commercial poultry farms. The layer chickens in which showed clinical symptoms of torticolis and curled toe paralysis, and hemorrhagic lesions in the lungs and / or digestive system are suspected of having AIV and NDV infections. After being necropsied, then lungs and gastrointestinal tract were tested IHC SB. The IHC SB results were examined with a digital microscope camera system. The results of the present study indicated that AIV antigen was detected in the lungs, but not in the digestive tract, whereas, NDV was detected in the digestive tract, but not in the lungs.

It was concluded, that the IHC SB can be applied for confirmation of the diagnosis of AIV and NDV and indicated, that the commercial laying chickens with clinical symptoms of torticolis and curled toe paralysis, as well as pathological hemorrhagic lesions in the gastrointestinal tract could be infected by both viruses.
\end{abstract}

Keywords: AIV, NDV, IHC SB, torticolis, paralysis

\begin{abstract}
Abstrak
Unggas tidak hanya dapat terinfeksi oleh satu jenis virus, tetapi dapat juga terinfeksi oleh lebih dari satu jenis virus. Virus avian influenza dan Newcastle disease adalah dua patogen penting pada unggas yang dapat menyebabkan wabah berulang dan seringkali menimbulkan gejala klinis dan lesi patologis yang serupa pada unggas dengan morbiditas dan mortalitas tinggi sehingga menyebabkan kerugian ekonomis yang besar pada industri perunggasan. Penelitian ini bertujuan untuk mendeteksi AIV dan/atau NDV pada ayam petelur komersial dengan gejala klinis serupa, terutama tortikolis dan paralisis kaki serta lesi patologis anatomis berupa foki nekrotik hemoragis pada saluran pencernaan dengan uji imunologis imunohistokimia streptavidin biotin (IHK SB). Sampel diambil dari kasus-kasus penyakit pada unggas di peternakan ayam petelur komersial. Ayam petelur tersebut menunjukkan gejala klinis tortikolis dan paralisis kaki, serta lesi hemoragis pada paru-paru dan/atau sistem pencernaan yang diduga terinfeksi AIV dan NDV. Setelah unggas dinekropsi, paru-paru dan saluran pencernaan diuji IHK SB kemudian diamati di bawah microscope digital camera system. Hasil penelitian ini membuktikan, bahwa dengan pewarnaan IHK SB, antigen AIV dapat dideteksi pada paru-paru, tetapi tidak pada saluran pencernaan, sedangkan NDV dapat dideteksi pada saluran pencernaan, tetapi tidak pada paru-paru. Berdasarkan hasil penelitian ini disimpulkan, bahwa IHK SB dapat diaplikasikan untuk peneguhan diagnosis AIV dan NDV dan terbukti, bahwa pada ayam petelur komersial dengan gejala klinis tortikolis dan paralisis kaki, serta lesi patologis hemoragis pada saluran pencernaan terinfeksi kedua macam virus tersebut.
\end{abstract}

Kata kunci: AIV, NDV, IHK SB, tortikolis, paralisis 


\section{Pendahuluan}

Avian influenza virus (AIV) dan Newcastle disease virus (NDV) adalah dua patogen penting pada unggas yang dapat menyebabkan wabah berulang dan seringkali menimbulkan gejala klinis dan lesi patologis yang serupa pada unggas dengan morbiditas dan mortalitas tinggi sehingga menyebabkan kerugian ekonomis yang besar pada industri perunggasan. Wabah avian influenza virus (AIV) merupakan penyakit unggas menular yang disebabkan oleh virus influenza tipe A, famili Orthomyxoviridae. Penyakit AI dilaporkan mewabah di Indonesia pada akhir tahun 2003 dan diketahui sebagai subtipe H5N1. Berdasarkan patogenisitasnya, AIV dibedakan menjadi highly pathogenic avian influenza (HPAI) dan low pathogenic avian influenza (LPAI). Virus AI terutama subtipe $\mathrm{H} 5$ dan $\mathrm{H} 7$ yang termasuk HPAI mampu menyebabkan morbiditas dan mortalitas yang tinggi pada ternak ayam komersial di Indonesia, serta dapat menyebabkan infeksi sistemik pada berbagai organ unggas (Alexander, 1982; Swayne and PantinJackwood 2008; Wasito et al., 2014). Di Indonesia, LPAI berhasil diisolasi dari itik dan burung pelikan pada tahun 1983 (Ronohardjo dkk., 1985). Infeksi LPAI diketahui menyebabkan morbiditas tinggi $(>50 \%)$ dan mortalitas rendah $(<5 \%)$, tetapi laju mortalitas dapat sangat tinggi pada unggas muda jika disertai infeksi patogen sekunder (Swayne and Pantin-Jackwood, 2008). Gejala klinis LPAI, berupa perubahan patofisiologis pada saluran pernapasan, pencernaan, reproduksi, dan urinaria (Swayne and Pantin-Jackwood, 2008).

Penyakit ND pertama kali terjadi di Indonesia, yaitu Pulau Jawa pada tahun 1926 (Quinn et al., 2002). Pada awal tahun 2011, kasus ND mewabah pada peternakan ayam pedaging secara merata di Sumatra, Jawa, Bali, Kalimantan dan Sulawesi dan meningkat jika dibandingkan dengan yang terjadi pada tahun 2009 dan 2010. Penyakit ND disebabkan oleh galur virulen serotipe avian paramyxovirus tipe 1 (APMV1), genus Avulavirus, subfamili Paramyxovirinae, famili Paramyxoviridae (Alexander and Senne, 2008). Berdasarkan tingkat virulensinya pada ayam, NDV dibagi menjadi tiga patotipe, yaitu tipe velogenik (sangat virulen), mesogenik (virulensi rendah) dan lentogenik (kurang virulen) (Quinn et al., 2002; Pattison et al., 2008). Pada umumnya, NDV virulensi rendah menyebabkan penyakit subklinis dengan morbiditas rendah, sedangkan isolat NDV virulen dapat mengakibatkan kematian yang cepat pada unggas (Kapczynski et al., 2013).

Virus ND kadang-kadang bersama dengan AIV menginfeksi unggas dan memiliki kesamaan yang signifikan dengan AIV dalam menyebabkan kematian pada unggas di industri perunggasan (Ge et al., 2007). Gejala klinis NDV pada unggas berupa gejala syaraf yang menonjol yang menunjukkan, ataksia, hilang keseimbangan, kepala berputar-putar tidak beraturan (tortikolis) ataupun rebah di atas punggung, paralisis kaki (Alexander and Senne, 2008; Cattoli et al., 2011). Gejala klinis NDV tersebut mirip dengan gejala klinis pada unggas yang terinfeksi AIV (Perkins and Swayne, 2001; Cattoli et al., 2011) dengan tingkat mortalitasnya mencapai 100\% (Pattison et al., 2008). Hal tersebut terlihat pada kasus penyakit ayam yang dibawa ke Laboratorium Patologi, Fakultas Kedokteran Hewan, Universitas Gadjah Mada maupun yang ditemukan di lapangan, sehingga menyulitkan dalam peneguhan diagnosis. Metode diagnostik saat ini, seperti isolasi virus dan pemeriksaan serologis konvensional, memakan waktu dan tenaga yang intensif, maka metode yang cepat dan sensitif dibutuhkan untuk mendeteksi dan membedakan antara virus-virus tersebut. 
Metode imunologis imunohistokimia telah diaplikasikan sebagai uji kualitatif yang efektif, akurat, mudah dilaksanakan, dan biaya terjangkau untuk mendeteksi keberadaan antigen virus pernafasan unggas, seperti virus AI (Rimmelzwaan et al., 2001; Gu et al., 2007; Kalthoff et al., 2008; Chamnanpood et al., 2011) dan NDV (Oldoni et al., 2005; Wakamatsu et al., 2006). Penelitian ini bertujuan untuk mengetahui dan menentukan aplikasi uji imunologis imunohistokimia streptavidin biotin (IHK SB) untuk mendeteksi virus, terutama AIV dan NDV penyebab penyakit pada ayam petelur komersial dengan gejala klinis serupa, terutama tortikolis dan paralisis kaki, serta lesi patologis anatomis berupa perdarahan berbintik pada saluran pencernaan. Selain itu, untuk mendeteksi apakah penyakit pada ayam petelur komersial dengan gejala klinis serupa tersebut disebabkan oleh infeksi campuran antara AIV dan NDV. Dengan penerapan uji IHK SB yang cepat, tepat, dan akurat, serta efisien dan efektif dalam peneguhan diagnosis infeksi campuran AIV dan NDV yang berdasarkan gejala klinis dan lesi patologis terlihat serupa, diharapkan dapat membantu dalam penentuan strategi pencegahan dan pengendalian yang tepat dalam upaya biosurveillance, biosecurity dan biosafety terhadap kedua macam virus tersebut.

\section{Materi dan Metode}

\section{Sampel penelitian}

Sampel yang digunakan pada penelitian ini diperoleh dari kasus-kasus lapangan di peternakan ayam petelur komersial di Jawa Tengah (tahun 2013-2015) dan sampel koleksi Laboratorium Patologi dan Laboratorium Ilmu Penyakit Dalam, Fakultas Kedokteran Hewan, Universitas Gadjah Mada. Sampel unggas diambil dari peternakan ayam petelur yang memiliki gejala gangguan sistem syaraf, berupa tortikolis dan paralisis, serta lesi hemoragis pada paru-paru dan/atau sistem pencernaan. Sampel yang digunakan berupa jaringan (usus dan paruparu) kemudian difiksasi formalin 10\% untuk uji imunopatologis IHK SB.

\section{Uji imunopatologis imunohistokimia streptavidin} biotin

Pada awalnya untuk uji imunopatologis imunohistokimia streptavidin biotin, sediaan histopatologis paru-paru dan proventrikulus (preparat) di-deparafinisasi dengan xilen 3 kali, rehidrasi dengan larutan etanol konsentrasi bertingkat menurun, yaitu 100\%, 95\%, dan 50\%, masing-masing 2 menit. Selanjutnya, dicuci dengan aquades 2 kali, kemudian PBS pH 7,2 1 kali. Pada proses awal, preparat ditandai dengan pap pen untuk menghindari tumpahnya reagensia pada saat proses pewarnaan. Selanjutnya, preparat direndam dalam peroxidase quenching solution (hidrogen peroksida/ $\mathrm{H}_{2} \mathrm{O}_{2} 3 \%$ ) yang dibuat dari campuran $30 \% \mathrm{H}_{2} \mathrm{O}_{2}(1$ bagian $)$ dan metanol absolut (9 bagian) selama 10 menit untuk menginaktifasi aktifitas peroksidase endogen, dicuci PBS pH 7,2 3 kali. Selanjutnya, dilakukan pewarnaan imunohistokimia streptavidin biotin (IHK SB) (Invitrogen, produk Histostain ${ }^{\circledR}$ SP). Pada awalnya, preparat diletakkan pada staining chamber dan diberi perlakuan dengan urutan sebagai berikut: a. Diberi 2 tetes $(100 \mu 1)$ serum blocking solution dan diinkubasi 10 menit. Selanjutnya, preparat diberi 2 tetes $(100 \mu 1)$ antibodi primer (antibodi poliklonal anti-nukleoprotein AIV atau antibodi poliklonal antinukleoprotein NDV), diinkubasi 45 menit, dan dicuci dengan larutan PBS pH 7,2 3 kali masing-masing 2 menit, b. Preparat diberi 2 tetes $(100 \mu 1)$ biotinylated secondary antibody dan diinkubasi 10 menit, dicuci 
dengan larutan PBS pH 7,2 3 kali masing-masing 2 menit, c. Preparat diberi 2 tetes $(100 \mu 1)$ enzyme conjugate (streptavidin-horseradish peroxidase) dan diinkubasi 10 menit, dicuci dengan larutan PBS pH 7,2 3 kali masing-masing 2 menit, d. Preparat diberi 2 tetes $(100 \mu 1)$ kromogen diaminobenzidine (DAB) dan diinkubasi 3 menit, kemudian dicuci dengan $\mathrm{H}_{2} \mathrm{O}$ steril. Larutan kromogen DAB dibuat dari campuran masing-masing 1 tetes bufer substrat $\mathrm{DAB}$, reagensia larutan kromogen $\mathrm{DAB}$, reagensia larutan substrat dan $1 \mathrm{ml} \mathrm{H}_{2} \mathrm{O}$, e. Preparat diberi 2 tetes $(100 \mu \mathrm{l})$ hematoksilin sebagai pewarna dasar dan diinkubasi 1 menit, lalu dicuci $\mathrm{H}_{2} \mathrm{O}$ steril, kemudian dimasukkan ke dalam larutan PBS pH 7,2 30 detik, dicuci kembali dengan $\mathrm{H}_{2} \mathrm{O}$ steril. Selanjutnya, dilakukan dehidrasi pada preparat dengan cara preparat dimasukkan secara berturut-turut ke dalam larutan etanol 50\%, 95\%, 100\%, dan xilen masing-masing 1 menit dan f. Preparat diberi 2 tetes $(100 \mu 1)$ mounting solution dan ditutup gelas penutup, kemudian diamati dengan microscope digital camera system.

\section{Analisis Data}

Sediaan jaringan yang telah diuji imunopatologis imunohistokimia streptavidin-biotin diperiksa di bawah mikroskop camera digital system dan dianalisis secara deskriptif.

\section{Hasil dan Pembahasan}

Penyakit AI dan ND adalah keprihatinan utama pada peternakan unggas, karena kerugian ekonomis yang tinggi bagi industri perunggasan dan infeksi parah pada unggas dengan angka kematian yang tinggi (Capua and Alexander, 2009). Beberapa tahun terakhir, diketahui bahwa unggas tidak hanya dapat terinfeksi oleh satu jenis virus, tetapi dapat juga terinfeksi oleh lebih dari satu jenis virus (Gelb et al., 2007). Virus AI dan ND adalah dua patogen unggas yang seringkali menimbulkan gejala klinis yang serupa dan dapat ditularkan antara unggas liar dan peliharaan (Alexander, 2000; Achenbach and Bowen, 2011). Hal tersebut menyebabkan kesulitan dalam eradikasi secara cepat dan tepat AIV dan NDV sehingga menyebabkan kerugian yang sangat signifikan pada peternakan ayam petelur komersial. Dengan demikian, diperlukan aplikasi metode diagnostik yang cepat, tepat dan akurat dalam rangka peneguhan diagnosis sehingga upaya pencegahan dan pengendalian, bahkan eradikasi penyakit AIV dan NDV pada ayam petelur komersial dapat dilakukan secara optimal. Sampel berasal dari ayam petelur komersial yang diduga terinfeksi AIV dan NDV berdasarkan gejala klinis yang muncul di lapangan berupa tortikolis dan paralisis kaki, serta lesi patologis anatomis berupa perdarahan berbintik pada saluran pencernaan.

Pada penelitian ini, berdasarkan hasil pewarnaan IHK SB untuk deteksi AIV maupun NDV pada ayam petelur komersial menunjukkan, bahwa antigen AIV dapat dideteksi pada paru-paru (Gambar 1), tetapi tidak pada saluran pencernaan. Sedangkan, NDV dapat dideteksi pada saluran pencernaan (proventrikulus) (Gambar 2), tetapi tidak pada paruparu (Gambar 3). Pada pengamatan dengan mikroskop cahaya, antigen tersebut terlihat berupa bintik-bintik coklat kemerahan yang mengelompok di suatu area atau menyebar pada seluruh lokasi jaringan. Adanya horseradish peroksidase (HRP) sebagai enzim pada ikatan antigen-antibodi kompleks menyebabkan terjadinya perubahan warna saat diberikan substrat. Kromogen yang digunakan dalam metode ini adalah diaminobenzidine (DAB) sehingga sel-sel yang positif terinfeksi virus akan terlihat berwarna coklat 
pada sitoplasmanya, sedangkan pada hasil negatif tidak ditemukan adanya warna coklat (Adi dkk, 2012).

Pewarnaan IHK SB membuktikan, bahwa aktifitas antibodi primer bersifat spesifik untuk deteksi adanya antigen NDV dan AIV. Pada penelitian ini, digunakan metode streptavidin-biotin karena streptavidin mempunyai kemampuan mengikat biotin lebih banyak dan lebih kuat (Warnke and Levy, 1980; Wasito, 1991).

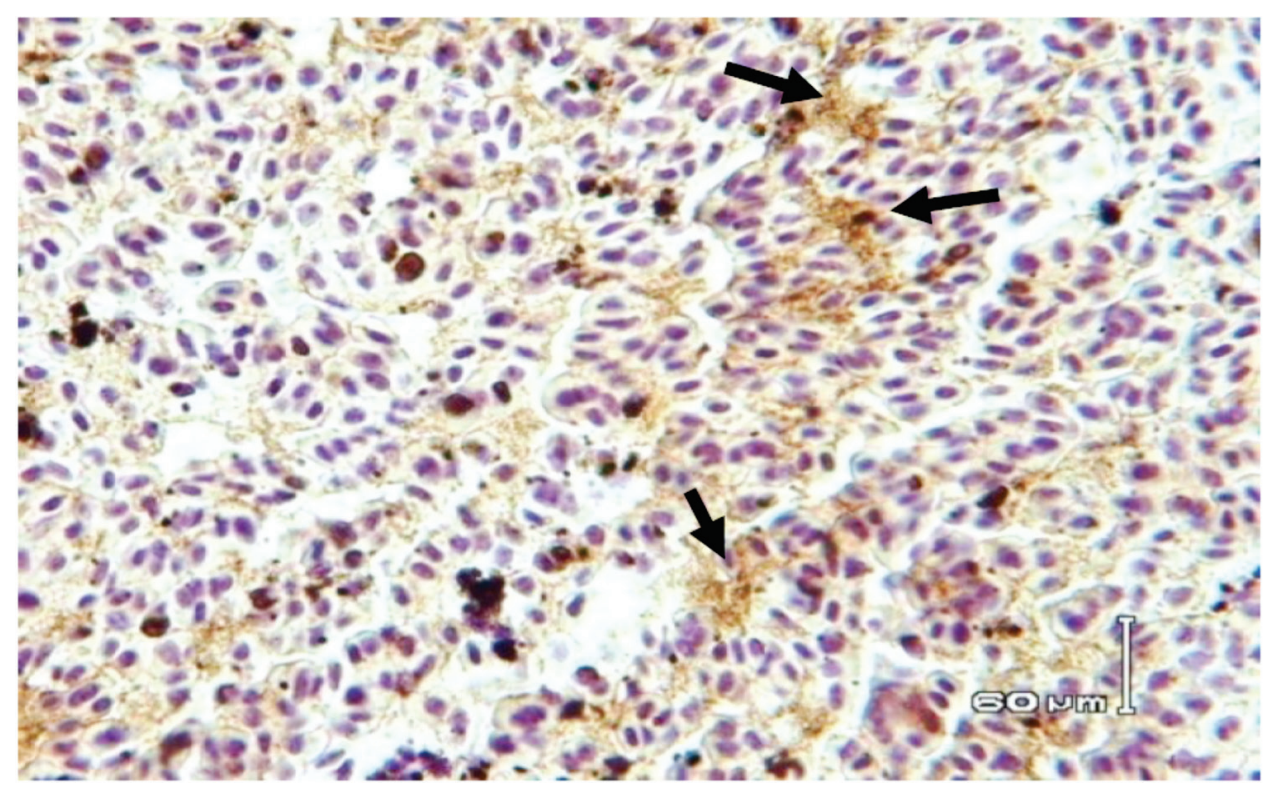

Gambar 1. Gambaran imunopatologis imunohistokimia streptavidin biotin dengan antibodi poliklonal anti-nukleoprotein avian influenza virus (AIV) pada ayam petelur komersial dengan gejala klinis tortikolis, paralisis kaki dan hemoragis proventrikulus. Paru-paru terlihat positif terinfeksi AIV terlihat berwarna coklat kemerahan (panah) (Streptavidin biotin).

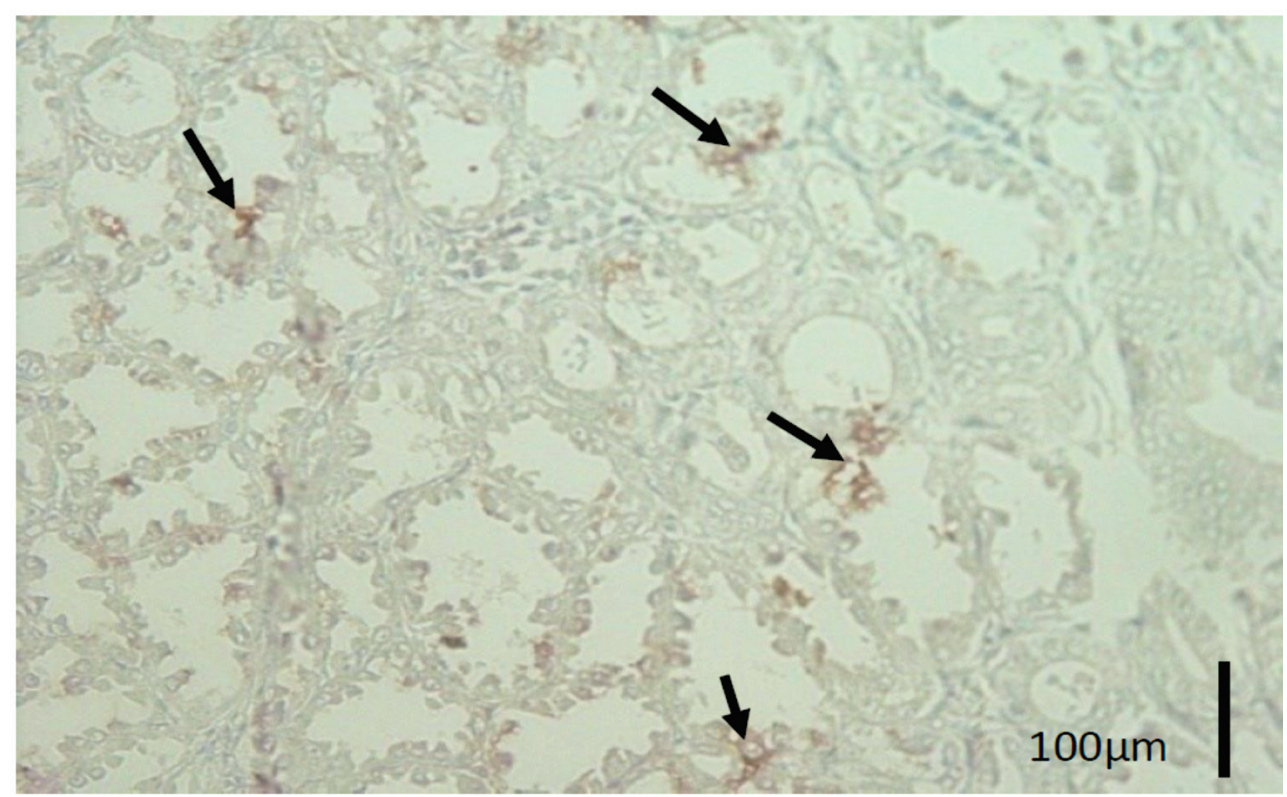

Gambar 2. Gambaran imunopatologis imunohistokimia streptavidin biotin dengan antibodi poliklonal anti-nukleoprotein Newcastle disease virus (NDV) pada ayam petelur komersial dengan gejala klinis tortikolis, paralisis kaki dan hemoragis proventrikulus. Proventrikulus terlihat positif terinfeksi NDV terlihat berwarna coklat kemerahan (panah) (Streptavidin biotin). 


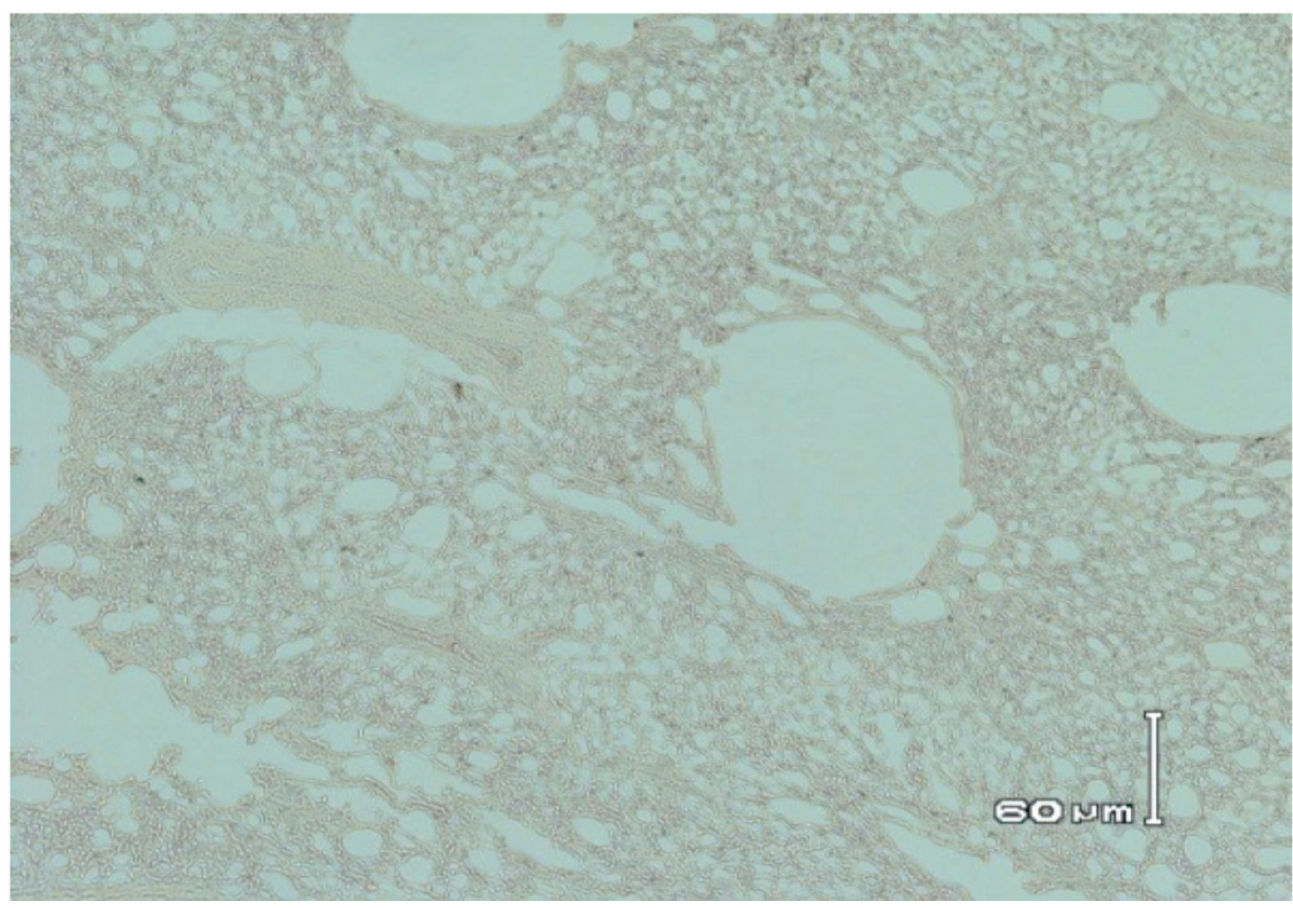

Gambar 3. Gambaran imunopatologis imunohistokimia streptavidin biotin pada paruparu ayam petelur komersial dengan gejala klinis tortikolis, paralisis kaki dan hemoragis pada proventrikulus sebagai kontrol negatif. Tidak terlihat adanya warna coklat (negatif) (Streptavidin biotin).

Berbagai penelitian yang telah dilakukan membuktikan, bahwa infeksi campuran virus pada hewan maupun tumbuhan merupakan fenomena yang biasa terjadi (Gelb et al., 2007). Koinfeksi AIV dan NDV yang telah dipelajari in vitro menunjukkan, bahwa kedua virus tersebut dapat saling menghambat pertumbuhan satu sama lain. Virus AI dapat mengganggu pertumbuhan NDV jika kedua virus tersebut diinokulasi pada saat bersamaan, namun tingkat gangguan tersebut tergantung pada kuantitas dan virulensi kedua galur virus yang digunakan. Jika NDV diinokulasi terlebih dulu, maka NDV dapat mengganggu pertumbuhan AIV (Ge et al., 2012). Efek replikasi virus juga berbeda, tergantung pada spesies unggas dan waktu infeksi. Hal tersebut menunjukkan, bahwa infeksi dengan virus heterolog dapat mengakibatkan persaingan sementara untuk reseptor sel atau sel yang kompeten untuk replikasi virus-virus tersebut (Costa-Hurtado et al., 2014).
Pada penelitian ini, digunakan antibodi poliklonal anti-nukleoprotein AIV dan antibodi poliklonal anti-nukleoprotein NDV untuk dapat mengenali banyak epitop AIV dan NDV sehingga memberikan deteksi yang kuat dan lebih toleran terhadap sedikit perubahan antigen di alam (Anonim, 2007). Berdasarkan pemeriksaan lesi patologis anatomis, pada penelitian ini, AIV yang terdeteksi termasuk low pathogenic avian influenza (LPAI) karena lesi patologis hanya ditemukan pada paruparu dan saluran pencernaan. Pada highly pathogenic avian influenza (HPAI), lesi patologis anatomis tidak hanya terdapat pada paru-paru dan saluran pencernaan, tetapi menyebar pada organ-organ lain (Capua and Alexander, 2009).

Walaupun secara alami AIV dan NDV virulen mampumenginfeksi dan berkembang biak pada semua sel, jaringan atau organ pada ayam (Wakamatsu et al., 2006), namun pada penelitian ini tidak semua sampel 
organ ayam yang diamati menunjukkan adanya antigen (AIV dan NDV). Tidak terdeteksinya antigen AIV pada saluran pencernaan ayam petelur dengan lesi patologis hemoragis kemungkinan karena sangat ekstensifnya lesi pada jaringan tersebut (Vascellari et al., 2007), dan kemungkinan terjadinya degradasi materi genetik akibat proses parafin embedding (Farmilo and Stead, 2009). Terdeteksinya AIV pada paru-paru menunjukkan, tersedianya protease yang diperlukan untuk replikasi AIV. Terdapat hubungan antara kadar RNA virus dalam paru-paru yang terinfeksi primer dengan kemungkinan distribusi sistemik melalui sirkulasi darah (Post et al., 2013). Tidak adanya NDV yang dapat terdeteksi pada paruparu merupakan gambaran, bahwa paparan infeksi secara alami menyebabkan virus hanya berada dalam sirkulasi darah (Damayanti dkk., 2004). Ada kemungkinan juga, bahwa ayam mengalami viremia sehingga virus ada dalam sirkulasi darah, dan belum sampai pada organ sasaran (organ predileksi) (Quinn et al., 2002). Selain itu, keberadaan sisi reseptor yang sama untuk AIV dan NDV memungkinkan terjadinya kompetisi antara kedua virus tersebut untuk pengikatan pada reseptor asam sialat di permukaan sel hospes. Hasil penelitian ini membuktikan, bahwa ada infeksi campuran AIV dan NDV pada ayam petelur komersial di lapangan dengan gejala klinis tortikolis dan paralisis kaki, serta lesi patologis berupa perdarahan berbintik pada saluran pencernaan.

Uji imunopatologis imunohistokimia streptavidin biotin perlu diaplikasikan sebagai uji rutin program di Laboratorium veteriner untuk peneguhan diagnosis AIV dan/ atau NDV pada kasus-kasus ayam petelur komersial di lapangan yang menunjukkan gejala klinis, antara lain: tortikolis, paralisis kaki dan hemoragis saluran pencernaan. Perlu diteliti lebih lanjut galur NDV (kemungkinan
NDV genotipe VII) yang dapat menyebabkan infeksi campuran dengan AIV pada ayam petelur komersial di peternakan unggas di Indonesia.

\section{Ucapan Terima Kasih}

Penulis mengucapkan terima kasih kepada Prof. drh.R.Wasito, M.Sc., Ph.D. dan Prof. drh. Hastari Wuryastuty, M.Sc., Ph.D., Fakultas Kedokteran Hewan, Universitas Gadjah Mada, atas bantuan dana penelitian, bimbingan, nasihat, dan arahan dalam penelitian dan penyusunan naskah ini.

\section{Daftar Pustaka}

Anonimus, 2007, Introduction to Antibodies, (Diakses tanggal 3 februari 2015).

Achenbach, J.E. and Bowen, R.A., 2011, Transmission of Avian Influenza A Viruses Among Species in an Artificial Barnyard, PLoS One, 6 (3): e17643.

Adi, A.A.A.M., Kardena, I.M, Astawa, N.M. and Matsumoto, Y., 2012, Pelacakan Secara Imunohistokimiawi Antigen Virus pada Ayam yang Diinfeksi dengan Virus Penyakit Tetelo, J.Vet., 13. (3): 278-283.

Alexander, D.J. and Stuart, J.C., 1982, Isolation of An Influenza A Virus from Domestic Fowl in Great Britain, Vet. Rec., 111:416.

Alexander, D. J., 2000, Newcastle Disease and Other Avian Paramyxoviruses, Rev. Sci. Off.Int. Epiz., 19, 443-462.

Alexander, D.J. and Senne, D.A., 2008, Newcastle Disease, Other Avian Paramyxovirus and Pneumovirus Infection In: Alexander and Senne, Y.M. (ed.), Disease of Poultry. Blackwell Publishing. Iowa. 75-92.

Capua, I. and Alexander, D.J., 2009, Ecology, Epidemiology and Human Health, Implications of Avian Influenza Virus Infections, Avian 
Influenza and Newcastle Disease, @SpringerVerlag Italia.

Cattoli, G., Susta, L., Terregino, C. and Brown, C., 2011, Newcastle Disease : A Review of Field Recognition and Current Methods of Laboratory Detection, J.Vet. Diagn. Invest., 23: 637-658.

Chamnanpood , C., Sanguansermsri, D., Pongcharoen, S. and Sanguansermsri, P., 2011, Detection of Distribution of Avian Influenza H5N1 Virus By Immunohistochemistry, Chromogenic In Situ Hybridization and Real-Time PCR Techniques In Experimentally Infected Chickens, Southeast Asian J. Trop. Med. Pub. Health, 42.(2): 303-310.

Costa-Hurtado, M., Afonso, C.L., Patti J Miller, Spackman, E., Kapczynski, D.R., Swayne, D.E., Shepherd, E., Smith, D., Zsak, A. and Pantin-Jackwood, M., 2014, Virus Interference between H7N2 Low Pathogenic Avian Influenza Virus and Lentogenic Newcastle Disease Virus in Experimental Co-Infections in Chickens and Turkeys, Vet. Res., 45: 1.

Damayanti, R., Dharmayanti, N.L.P.I, Indriani, R., Wiyono, A., Darminto, 2004, Gambaran Klinis dan Patologis pada Ayam yang Terserang Flu Burung Sangat Patogenik (HPAI) di Peternakan di Jawa Timur dan Jawa Barat, JITV, 9. (2): 128-135.

Farmilo, A.J. and Stead, R.H., 2009, Fixation and Proccesing. In Educational Guide Immunohistochemistry Staining Methods, $5^{\text {th }}$ edition, Dako North America, Carpinteria, California.

Ge, J., Deng, G., Wen, Z., Tian, G., Wang, Y., Shi, J., Wang, X., Li, y., Hu, S., 2007, Newcastle Disease Virus Based Live Attenuated Vaccine Completely Protecs Chickens and Mice From Lethal Challenge of Homologous and Heterologous H5N1 Avian Influenza Viruses, J. Virol., 150-158.

Gelb, J., Ladman, B.S., Licata, M.J., Shapiro, M.H., Campion, L.R., 2007, Evaluating Viral Interference Between Infectious Bronchitis Virus and Newcastle Disease Virus Vaccine Strains Using Quantitative Reverse
Transcription-Polymerase Chain Reaction, Avian Dis., 51:924-934.

Gelb, J., Ladman, B.S., Licata, M.J., Shapiro, M.H., Campion, L.R., 2007, Evaluating Viral Interference Between Infectious Bronchitis Virus and Newcastle Disease Virus Vaccine Strains Using Quantitative Reverse Transcription-Polymerase Chain Reaction, Avian Dis., 51:924-934.

Gu, J, Xie, Z, Gao, Z., 2007, H5N1 Infection of The Respiratory Tract and Beyond: A Molecular Pathology Study, Lancet, 370: 1137-1145.

Kalthoff, D., Breithaupt, A., Teifke, J.P., 2008, Highly Pathogenic Avian Influenza Virus (H5N1) in Experimentally Infected Adult Mute Swans, Emerg. Infect. Dis., 14: 1267-70.

Kapczynski, D.R., Afonso, C.L. and Miller, P.J., 2013, Immune Responses of Poultry to Newcastle Disease Virus, Develop. Comp. Immuno., 41:447-453.

Oldoni, I., Brown, C.C., King, D.J., and other authors, 2005, The Use of In Situ Hybridization and Immunohistochemistry to Study The Pathogenesis of Various Newcastle Disease Virus Strains and Recombinants in Embryonated Chicken Eggs, Micro. Pathog., 39: 69-75.

Perkins, L.E.L. and Swayne, D.E., 2001, Pathobiology of A/Chicken/Hong Kong/220/97 (H5N1) Avian Influenza Virus in Seven Gallinaceous Species, Vet. Pathol., 38:149-164.

Pattison, M., McMullin, P.F., Bradbury, J.M. and Alexander, D.J., 2008, Poultry Diseases, $6^{\text {th }}$ Edition, Saunders Elsevier, China, pp: 298301.

Post, J., de Geus, D.G., Vervelde, L., Cornelissen, J.B.W.J. and Rebel, J.M.J., 2013, Systemic Distribution of Different Low Pathogenic Avian Influenza (LPAI) Viruses in Chicken, $J$. Virol., 10:23.

Quinn, P.J., Markey, B.K., Carter, M.E., Donnelly, W.J.C. and Leonard, F.C., 2002, Veterinary Microbiology and Microbial Disease, Blackwell Science. Iowa. 283-289, 308, 381-387. 
Rimmelzwaan, G.F., Kuiken, T., Amerongen, G.V., Bestebroer, T.M., Fouchier, R.A.M., Osterhaus, A.D.M.E., 2001, Pathogenesis of Influenza A (H5N1) Virus Infection in A Primate Model, $J$. Virol, 75: 6687-91.

Ronohardjo, P., Hardjosworo, S., Partoatmojo, S. and Partadireja, M., 1985, The Identification and Distribution of Influenza A Virus in Indonesia, Penyakit Hewan XVII, Semester I: 249-257.

Spackman, E., 2008, A Brief Introduction to The Avian Influenza Virus, Methods Mol. Biol., 436, 1-6.

Swayne, D.E. and Pantin-Jackwood, M., 2008, Pathobiology of Avian Influenza Virus Infections in Birds and Mamals, Blackwell Publishing Professional 2121 State Avenue, Ames Iowa 50014, USA: 87-122.

Vascellari, M., Granato, A., Trevisan, L., Basilicata, L., Toffan, A., Milani, A. and Mutinelli, F., 2007, Pathologic Findings of Highly Pathogenic Avian Influenza Virus A/Duck/Vietnam/12/05 (H5N1) on Experimentally Infected Pekin Ducks, Based on Immunohistochemistry and In Situ Hybridization, Vet. Pathol., 44: 635642.

Wakamatsu, N., King, D.J., Kapczynski, D.R., Seal, B.S., Brown, C.C., 2006, Experimental
Pathogenesis For Chickens, Turkeys, And Pigeons of Exotic Newcastle Disease Virus from An Outbreak in California During 20022003, Vet. Pathol., 43:925-933.

Wakamatsu, N., King, D.J., Seal, B.S., Brown, C.C., 2007, Detection of Newcastle Disease Virus RNA by Reverse Transcription-Polymerase Chain Reaction Using Formalin-Fixed, Paraffin-Embedded Tissue and Comparison with Immunohistochemistry and In Situ Hybridization, J. Vet .Diagn. Invest., 19:396-400.

Warnke, and Levy, R., 1980, Detection of T and B Cell Antigens with Hybridoma Monoclonal Antibodies: Biotin Avidin Horseradish Peroxidase Method, J. Histochem. Cytochem., 28: 771 .

Wasito, R., 1991, Penggunaan Imunositokimia untuk Diagnosis Penyakit Infeksi, Kursus Singkat Imunositokimia di PAU Bioteknologi, Universitas Gadjah Mada, Yogyakarta.

Wasito, R., Wuryastuty, H., Tjahyowati, G., Irianingsih, S. H., Tyasasmaya, T. and Maes, R. K., 2014, Detection and Differentiation of Pathogenic H5 and H7 Influenza A Virus Subtypes in Indonesian Poultry by Multiplex Reverse Transcription-Polymerase Chain Reaction, Biochem. and Biotech. Res., 2(2): 27-31. 